\title{
How Investment Deposits at Islamic and Conventional Banks Effect Earnings Per Share?
}

\author{
Sanaa Nazami MASWADEH ${ }^{1}$
}

Received: August 01, 2020 Revised: September 30, 2020 Accepted: October 15, 2020

\begin{abstract}
The study aims to compare the effects of employing investment deposits (joint and specified investment deposits) in Islamic banks, and investment deposits (term deposits and deposits with notification) at conventional banks, on shareholders' profitability, represented by the earnings per share (EPS), in light of operational profits as a controlling variable. Data related to the study variables was collected from the annual financial reports published by the study sample banks, during the period (2009-2018). The study relies on multiple regression to test the hypotheses of the study. The high adjusted $\mathrm{R}^{2}$ to explain the change in EPS for Islamic banks model as compared to conventional banks, is a result of the high difference between investment deposits (specified and joint) at Jordanian Islamic banks and investment deposits (term deposits and deposits with notification) at Jordanian conventional banks. The study found that it is important for the managements of Islamic banks to adopt a uniform method to combine speculative funds, in order to develop and improve shareholders' profitability. The study recommended Islamic banks to follow practical, methodological and transparent approaches to calculate the rates of Murabaha profit margins between shareholders and depositors, while also taking into consideration some of the issues which could be harmful for the competition between Islamic and conventional banks.
\end{abstract}

Keywords: Investment Deposits, Islamic Banks, Conventional Banks, Earnings per Share

JEL Classification Code: G21, G32, L25

\section{Introduction}

Due to the fact that the banking sector plays a vital role as an indicator of how advanced the economies of countries are, its importance has been on the rise. Hence, as the level of financial activities of any given country's banking sector increases, a positive effect on the general economy of the country can be seen. This is achieved by collecting savings from individuals or other various parties, whether these savings are unused by savers in the short term as they are not needed, or if they are unused in the long term, or even permanently, which implies a hoarding of funds. Banks contribute to developing economies by collecting funds and then investing it in various projects, including those which

${ }^{1}$ First Author and Corresponding Author. Professor, Accounting Department, School of Business, Jadara University, Irbid, Jordan [Postal Address: P.O. Box 733, Irbid 21110, Jordan]

Email:mmsana59@gmail.com

(c) Copyright: The Author(s)

This is an Open Access article distributed under the terms of the Creative Commons Attribution Non-Commercial License (https://creativecommons.org/licenses/by-nc/4.0/) which permits unrestricted non-commercial use, distribution, and reproduction in any medium, provided the original work is properly cited. are likely to lead to economic and social development, along with strengthening economic growth rates. This in turn leads to an overall improvement in the standard of living of members of the society.

A new form of banks has emerged in the mid of the $20^{\text {th }}$ century which carries a set of principles, characteristics and objectives that set them apart from the existing conventional banks such as Islamic Banks, which relied on a clear philosophy, namely, adherence with the teachings of tolerant Islam. Islamic banks have adopted a new banking system that sets them apart from other banks which rely on the concept of usurious interest. Their activities involve collecting or creating a pool of funds from various sources and investing them in accordance to Islamic Sharia. Moreover, Islamic banks are concerned with earning halal profits in compliance with Islamic Sharia, which includes achieving justice and putting to use the bank's pool of funds according to the appropriate Islamic path, while generating an acceptable return for shareholders without compromising the financial strength of the bank.

Investment accounts at Islamic banks are considered as a substitute to term accounts (term deposits or deposits with notification) at conventional banks (Babker, 2000). 
Attracting, managing and employing these deposits and accounts is considered to be one of the most prominent activities carried out by banks. Attraction of funds, which is the most important one, can be used for financing various investments and leading to growth, alongside banks' own funds collected from their shareholders (Al Ali, 2013). Deposits are considered to be one of the most important sources of funding for both conventional and Islamic banks. It is for this reason that banks pay particular attention to growing their respective deposit bases by competing with each other, through a number of tools such as increasing the number of branches in a country, simplifying procedures related to banking operations such as deposits and withdrawals, increasing the efficiency of various saving instruments, and developing and offering various commercial documents which are accepted as a means of payment after being endorsed. All of these activities lead to an increase in the number of investment opportunities, which in turn increase the banks' ability to achieve acceptable returns for their respective shareholders. This in turn helps them to attract new investors to the bank, and retain the existing shareholders, as their confidence grows in the institution. This is especially true in light of the agency theory of separation between management and ownership.

Based on all of this, it has become increasingly important to study and compare the performance of conventional and Islamic banks, along with their respective abilities to make profits through investing depositor funds in various investment projects, while ensuring justice and equity for both depositors seeking to invest their funds and shareholders seeking to expand their wealth by increasing their earnings per share. It is also important to gauge the efficiency of the banking system of a country as it reflects upon the efficiency and effectiveness of monetary and financial policies, which in turn reflect the level of development that societies have been able to achieve. Moreover, it is worthy to note that there are a wide range of financial and monetary policies which a central bank can choose from in order to achieve sustainable growth for the national economy, depending on the country's prevailing circumstances and social and economic objectives. Adopting the appropriate policies would have the effect of increasing banks' ability to compete regionally and internationally, ensuring the continuity and prosperity.

\section{The Problem of the Study}

The problem of this study emerged from the ongoing debate regarding the performance of conventional and Islamic banks, and their respective abilities to allocate investment funds in order to increase profits made for shareholders. We have attempted to compare both banks by answering the following question: what are the effects of employing investment deposits (term deposits and deposits with notification) at conventional banks, and investment deposits (joint and specified investment deposits) in Islamic banks, on shareholders' profitability, (represented by the earnings per share to each common stock), taking into consideration the presence of operational profits as a controlling variable, in order to consider the ability of these banks to achieve operational profits.

\section{The Importance of the Study}

Islamic banks operate on the principles of Islamic Sharia. They do not adopt the principle of usurious interest. Islamic banks have posed themselves on the international financial sector, and have received wide spread acceptance from many different segments of society. This has been possible due to the confidence and security they have been able to provide their customers, in addition to the profits they have been able to make over the years. All of this has led to popularity of the concept of Islamic banking. In light of the aggressive competition existing between Islamic and conventional banks, it has become ever so important to conduct a study on these two types of banks. This stems from the researchers' belief that Islamic and conventional banks are in need of an analytical study which deals with the banking sector's ability to develop new tools and instruments to attract funds and savings, and to direct them towards investment projects capable of generating returns, which are then distributed to the shareholders. This is important so as to increase shareholder confidence in the way banks operate, and in order to support and bolster the roles of banks in societies.

In addition to all this, the comparison between Islamic and conventional banks could contribute to developing the banking sector as a whole, enabling us to determine the best alternative amongst them. Islamic banking has offered many different investment formulas and instruments such as partnership contracts, sales contracts and leasing contracts. This diversification has offered the banks with a great deal of flexibility to meet the different financing requirements of their customers. It is worthy to note that a number of conventional banks have decided to establish Islamic branches or windows within their existing operations, so as to increase their efficiency and competitiveness both locally and on an international level, considering the significant profits which can be made from Islamic financing operations. Reaching related results regarding the effects of investment deposits on the profitability of Islamic and conventional banks, and presenting these results to the managements of the banks would be helpful in order to focus on the investment deposits which are most capable of expanding the wealth of shareholders and depositors at these banks. 
Moreover, this would bolster investor and depositor confidence, in a way which would provide these banks with a competitive advantage in an increasingly globalized and open market, characterized by a high level of competitiveness. Furthermore, studying the effect of investment deposits on the ability of banks to make profits is of great importance to shareholders. The generation of profits means that shareholders would make higher returns, whilst also increasing the market value of their shares, making it easier for them to continue with their investment in these shares or selling them. Hence, banks seek to continuously make profits, as they are considered to belong to the owners of the invested funds. It is for this reason that banks are also concerned with striking a balance between all concerned stakeholders, in a way that provides these institutions with a competitive advantage and sustainability. All of this reflects positively on local economies and societies.

\section{Contribution of the Study}

The subject of this study is considered to be one of the topics which can fundamentally contribute in building a theory around the banking operations and supporting its various applications. It also contributes to studying the effect of bank deposits on the ability to provide shareholders with profits. It is important to note that there is a clear difference between the activities carried out by Islamic and conventional banks when it comes to the sources and uses of funds. This leads to a stark difference between the balance sheet structure of both types of banks. Funds and deposits in Islamic banks are all considered to be risky funds, as these banks do not guarantee the principle amounts, nor do they provide fixed returns. Rather, owners of the funds are considered to be partners in the profits and losses that may be generated from the investments made by Islamic banks. Meanwhile, conventional banks offer fixed interests that have previously been agreed upon. It is for all of the abovementioned reasons that the present study on the effect of investment deposits on making profits to shareholders in conventional and Islamic banks, contributes to enhance the accounting literature. It also attempts to provide appropriate recommendations which may be taken advantage of to advance banking sector.

This study comes as a continuation and addition to previous studies. It is hoped that this study will enable researchers and scholars to expand upon the effect of investment deposits on the performance of the banking sector, whether Islamic or conventional, in addition to expanding their horizons in order to focus on various other variables which have not been touched upon within this study.

\section{Literature Review and Hypotheses}

Islamic banks have introduced a number of new banking mechanisms with many features, differing from those used at conventional banks to attract and mobilize savings and investments. They have also met the requirements of a broad segment of the Muslim public, who prefer to retain their funds over depositing them with conventional banks which pay usurious interest on deposits, while redirecting these funds to serve financial and economic development, thereby contributing to developing societies. Al Saifi and Al Salim (2010) state that Islamic banks collect funds from their customers with the aim of investing them in a number of specific areas, on the basis of specified investment, or joint/general 'mudaraba' contracts. These types of contracts govern the relationships between Islamic bank shareholders and the owners of investment deposits, hence, the rules and conditions of these types of accounts stem from the rules and conditions of partnership contracts.

According to Al Malkawi (2012), it is possible to distinguish between two types of investment deposits as follows: specified investment deposits, which are deposits received by Islamic banks from clients who wish to invest these funds in a specific or agreed upon project or aspect, noting that the bank is entitled to a certain share in the potential profits to be made from the project, on the condition that they do not violate any of the terms agreed upon. Joint or general investment deposits are funds received by Islamic banks from customers who wish to participate in the banks' financing or investing activities in an organized and continuous manner, without any conditions being imposed on the banks. In return, Islamic banks are entitled to a share in the potential profits to be made from these investment and financing operations, on the condition that they do not violate or breach any of the agreed upon terms (Abdullah and Saefan, 2011). Joint or general investment deposits at Islamic banks have been further categorized into three types: saving accounts (saving deposits), term accounts and accounts with notification, which are the same as the investment deposits at conventional banks (Saeed, 2014).

Term deposits are defined as deposits where the depositor is not allowed to recover before the end of a specified or agreed upon period of time. Hence, these types of deposits offer the bank with the greatest level of confidence in its credit operations. As for customers, they do not have the right to demand their deposit before the end of a specified period of time, though banks usually do allow for the liquidation and recovery of the deposit by the customer prior to the end of the maturity date in exchange for foregoing the customer's right to the interest that would have been paid for the period of time falling between the date of liquidation and the maturity date (Saeed, 2014). Deposits with notification are defined as cash deposits without any specified term maturity, whereby upon depositing these funds, the customer does not specify any date for withdrawing or recovering these funds. Moreover, the customer has the right to add funds to these types of deposits whenever he/she desires so. 
However, customers with these types of accounts are obliged to notify the bank about their desire to withdraw funds prior to the date of withdrawal by a specified period of time. In doing so, customers are obliged to inform the bank about how much they are planning to withdraw and when they plan to do so. Upon this specified date, the amount to be withdrawn is transferred to a deposit under demand account (Saeed, 2014). These deposits offer the bank with a certain level of freedom and confidence when it comes to its credit operations, especially if we compare them with deposits under demand accounts; however they are considered to offer the bank with less flexibility when it comes to term deposit accounts. Al Fasfoos (2010) defines savings accounts as those that are usually opened for small depositors. It is also possible for large depositors to take advantage of these services. Customers benefitting from this type of account are usually allowed to withdraw funds based on certain conditions related to the limits of withdrawal, the time period, and their share in the potential profits, in addition to losing the right for their accounts to participate in profits.

There are different studies on comparing the performances of conventional and Islamic banks. Saadah, and, Al Zaydanyeen, and Al Shaer (2017) studied the effect of using investment deposits on the profitability of Jordanian Islamic banks' shareholders during the period 2009 - 2015. The study sample included both the Jordanian Islamic Bank and the Arab International Islamic Bank. The study finds that there is a statistically significant effect of employing joint and specified deposits (investment accounts) on the EPS at Jordanian Islamic banks. This is attributed to the fact that these banks have followed numerous appropriate formulas and approaches to manage and employ their available investment deposits.

Baber (2019) investigates the effect of the modified e-SERVQUAL (e-SQ) model by adding Shariah compliance principles applicable on banks and products for Malaysian Islamic banking customers' perceptions that affect the performance of the banks. The finding specified that efficient \& reliable services, fulfillment, security/trust, and Shariah compliance principles have a significant effect on the performance of Islamic banks.

Usman and, Andriyani, and, Pambuko (2019) studied the productivity change of social funds and financial funds e.g., zakah, infaq, and sadaqah of Islamic Banks in Indonesia. The results indicate that social funds are more productive than financial funds and the productivity change of Islamic banks is influenced by technological aspect rather than the efficiency aspect. Overall, the study found that the policymakers may strengthen the management and coaching to increase the Islamic banks' productivity in both funds. Tabash (2019), studied the relation between disclosure and financial performance of Islamic banks in the United Arab Emirates, using predetermined variables like size, deposits, non-performing investments, and capital to risk-weighted assets ratio. The results show a significant correlation between disclosure and operating performance in the UAE Islamic banks. Better disclosure reduces equity costs and increases the value of Islamic banks in the market. Nguyen and Nguyen (2020), investigated the effect of the statement of cash flows on short-term and long-term borrowing decisions of commercial banks in Vietnam. The study shows the cash flow statements information affects both the long and shortterm borrowing decisions of credit officers and the lack of information on cash flow statement related to both negative and positive profits affects the confidence and comfort of decision making of credit officers in Vietnam.

Al Adwan (2014), studied the factors affecting the value of deposits, joint and specified investment accounts, in addition to current accounts at Jordanian Islamic banks. The study sample included the Jordanian Islamic Bank and the Arab International Islamic Bank, and had relied on the published financial reports for the two banks during the period 1999-2012. The study finds that there was a clear growth in the volume of current and joint investment deposits during the sample period for the study. This was in contrast to specified investment deposits, which were influenced by a number of internal and external factors. Al Rimawi (2014), tries to explain the most important risks faced by owners of joint (general) investment deposits at Jordanian Islamic banks, especially in light of the fact that these depositors are uninvolved in management and decision making. The study goes further in its attempt to compare these risks with those faced by depositors at conventional banks.

Al Sarayre (2010) examined the influence of internal and external factors on a number of Saudi conventional banks. The study sample included 10 banks during the period 19992006, and relied on the published financial reports of these banks in addition to banking sector financial indicators, alongside various macro-economic variables. The study concludes that there is a significant relationship between the profitability of banks, estimated by the rate of return on equity, and internal factors related to the rate of employing deposits, in addition to the capital adequacy ratio and the ratio of operational expenses. The study also concludes that there is a positive relationship between the profitability of banks and external factors related to the GDP growth rate and the development of the banking sector.

A study conducted by Al Saifi and Al Saleem (2010) examined the investment deposit contract, and how its profits are distributed, in addition to the parties included that this profit allocation or distribution. The study also examines the nature of Islamic Banking operations and how this affects profit allocation, in addition to a number of contemporary 
views on profit allocation when it comes to paid agencies or speculation/Al Mudarraba. The study reached a number of conclusions, most important of which are: An investment deposit contract is a profit-sharing contract rather than a paid agency contract or a power of attorney to carry out activities. Profits are shared between depositors and the bank in one of the following ways: The bank may be considered as a speculator which pools its funds with the speculative funds of its depositors, in which case the bank is compensated for its efforts and share of funding or the bank may be considered as an active partner, in which case it deserves a share of the profits according to the contract between it and its depositors.

In the study conducted by Rashdan (2009), which attempted to identify the internal factors influencing the profitability of Jordan Islamic Bank during the period 1980 - 2008. The study concluded that both the ratio of total expenses to total assets, and the ratio of total deposits to total assets, negatively affect the bank's profitability. The study conducted by Richardson (2011) examined the current legal status of Islamic financing in Ireland, in addition to the obstacles and difficulties being faced by those participating in Islamic financing for retail selling, alongside clarifying the status of taxes on these participants. The study concludes that in order for Islamic products to compete with their conventional banking counterparts, it is important to expand the scope of the legal text in banking laws so as to be more in line with Islamic principles and to clarify the legal transactions. In absence of these adjustments to the law in Ireland, including the tax laws, the burdens borne by Islamic financing for retail selling are still present, and will continue to prevent the emergence and development of Islamic financial activities in Ireland. In the light of previous literature review the study came to test the following main hypotheses:

H1: There is no statistically significant effect of investment deposits (specified and joint) in the light of operational income as a controlling variable, on the earnings per share for Islamic banks.

H2: There is no statistically significant effect of investment deposits (term deposits and deposits with notification) in the light of operational income as a controlling variable, on the earnings per share for conventional banks.

\section{Research Methodology}

This part includes a description of the procedures and methods used in the study. It also includes a definition of the study population and its sample, in addition to the sources of data and variable collection. Furthermore, this part shall describe the methods used to measure all this data, the statistical approaches used to reach the results and test the study's hypotheses.

\subsection{The Study's Population and Sample}

The study's population consists of three Jordanian Islamic banks, namely, the Jordanian Islamic Bank, the Arab International Islamic Bank, and Al Safwa Bank. Al Safwa Bank was not included in the study sample due to the lack of sufficient data in its annual financial reports for the period of the study, from 2009-2018. Therefore, the sample chosen included two Jordanian Islamic banks, namely: the Jordanian Islamic Bank and the Arab International Islamic Bank. The study's population also consisted of all conventional Jordanian banks, which, according to the Central Bank of Jordan annual report published at the end of 2018, were numbered at 14 . For the purpose of conducting the study and testing its hypotheses, and hence comparing between Islamic and conventional banks, two conventional banks were selected in a non-random manner in order to achieve homogeneity in the data to be subjected to statistical analysis. These banks are: Cairo Amman Bank and Jordan Kuwait Bank.

\subsection{Data Collection}

Basic data related to the study variables were collected from the annual financial reports published by the study sample banks, during the period 2009-2018. The study also relies on books, previous studies, periodicals, researches and various specialized databases related to the subject of the study.

\subsection{Statistical Methods}

The SPSS statistics-22 software was used to examine the data of the study and to test its hypotheses, in addition to ensuring the relevance of the data to regression test. The normal distribution hypothesis for the study was validated using the Shapiro-Wilk test, the variance inflation factor (VIF) test, and the tolerance test. Multi-collinearity test was used to examine collinearity between the independent variables. Also, central tendency measures i.e., mean and standard deviation, were used to obtain the descriptive characteristics for the study's variables. Finally the study relied on a multiple regression analysis to test the study hypotheses, so as to compare the effect of the investments deposits as independent variables on EPS for both Islamic and conventional banks in the light of operating income as control variable. 


\section{Empirical Results}

\subsection{Testing Data}

The Shapiro-Wilk test was used to determine whether the data was normally distributed or not. The results of the test are shown in the following table: Table 1 shows that the Sig is greater than $5 \%$ for all of the study's variables, which confirms that the data is normally distributed. The variance inflation factor and tolerance tests were used in order to analyze multiple collinearity between the independent variables. Our results are shown in Table 2.

Table 2 shows that the value of the VIF was less than 5 , while the tolerance coefficient was greater than $20 \%$. Both were within statistically acceptable limits, which can be considered as an indicator that there is no multiple collinearity between the various independent variables. Hence, we can accept the level of variance within each independent variable in the study. For the descriptive statistical tests conducted on the various independent variables, we conducted maxima, minima, a mean and standard deviation test, all of which were divided upon the total assets of each bank, and were then converted to percentages of bank total assets. This was done in order to be able to extract more indicative results. The results are shown in Table 3.

Table 3 shows the descriptive statistics for the study conducted from 2009-2018. It is clear that Islamic banks focus on joint deposits more significantly than they do on specified investment deposits, at rates of 0.507 and 0.0632 respectively, while conventional banks rely on deposits with notification more than they do on term deposits, at rates of 0.201 and 0.076 respectively. It is clearly shown from the mean deposits at banks in the table below, that the average EPS for conventional banks is higher than that for Islamic Banks, at rates 0.352 and 0.230 respectively.

Table 1: Shapiro-Wilk to Test the Normality of Data

\begin{tabular}{|l|c|c|}
\hline Variables & Statistics & SIG \\
\hline Specified Investment Deposits & 0.823 & 0.152 \\
\hline Joint Investment Deposits & 0.721 & 0.0961 \\
\hline Operating profit (for Islamic banks) & 0.878 & 0.162 \\
\hline EPS (for Islamic banks) & 0.933 & 0.173 \\
\hline Term Deposits & 0.925 & 0.123 \\
\hline Deposits with notification & 0.869 & 0.113 \\
\hline Operating profit (for Traditional Banks) & 0.955 & 0.457 \\
\hline EPS (for Traditional Banks) & 0.927 & 0.13 \\
\hline
\end{tabular}

Table 2: Multiple Collinearity between Independent Variables

\begin{tabular}{|l|c|c|}
\hline Variables & VIF & Tolerance \\
\hline Specified Investment Deposits & 1.125 & 0.889 \\
\hline Joint Investment Deposits & 1.230 & 0.813 \\
\hline Operating profit (for Islamic banks) & 1.262 & 0.793 \\
\hline Term Deposits & 1.319 & 0.758 \\
\hline Deposits with notification & 3.967 & 0.252 \\
\hline Operating profit (for Traditional Banks) & 3.705 & 0.270 \\
\hline
\end{tabular}

Table 3: Descriptive Statistical for the Study Variables

\begin{tabular}{|c|c|c|c|c|}
\hline Variables & Minimum & Maximum & Mean & Std. Deviation \\
\hline Specified Investment Deposits & 0.007 & 0.172 & 0.063 & 0.061 \\
\hline Joint Investment Deposits & 0.135 & 0.693 & 0.507 & 0.185 \\
\hline Operating profit(for Islamic banks) & 0.026 & 0.361 & 0.035 & 0.105 \\
\hline EPS(for Islamic banks) & 0.017 & 0.047 & 0.230 & 0.007 \\
\hline Term Deposits & 0.009 & 0.160 & 0.076 & 0.050 \\
\hline Deposits with notification & 0.017 & 0.424 & 0.201 & 0.139 \\
\hline Traditional Operating profit & 0.167 & 0.519 & 0.051 & 0.103 \\
\hline Traditional EPS & 0.044 & 0.059 & 0.352 & 0.005 \\
\hline
\end{tabular}


Table 4: Results of Multiple Regression Testing

\begin{tabular}{|c|c|c|c|c|c|c|c|c|}
\hline \multicolumn{4}{|c|}{$\begin{array}{c}\text { Islamic Model } \\
\qquad \operatorname{ES}_{i, t}=\alpha_{i, t}+\beta_{1} S D_{i, t}+\beta_{2} J D_{i, t}+\beta_{3} O P_{i, t}+\varepsilon_{i, t}\end{array}$} & \multirow{2}{*}{$\begin{array}{c}\mathbf{R} \\
0.917 \\
\end{array}$} & \multirow{2}{*}{$\begin{array}{c}\mathbf{R}^{2} \\
0.841 \\
\end{array}$} & \multirow{2}{*}{$\begin{array}{c}\begin{array}{c}\text { Adjusted } \\
\mathbf{R}^{\mathbf{2}}\end{array} \\
0.811 \\
\end{array}$} & \multirow{2}{*}{$\begin{array}{c}\text { F } \\
28.164 \\
\end{array}$} & \multirow{2}{*}{$\begin{array}{l}\text { Sig. } \\
0.000\end{array}$} \\
\hline variables & Coefficient (B) & $\mathbf{t}$ & Sig. & & & & & \\
\hline Constant & 0.211 & 2.884 & 0.011 & & & & & \\
\hline $\begin{array}{l}\text { Specified } \\
\text { Investment } \\
\text { Deposits }\end{array}$ & 0.032 & 0.273 & 0.788 & & & & & \\
\hline $\begin{array}{l}\text { Joint Investment } \\
\text { Deposits }\end{array}$ & 1.365 & 4.375 & 0.000 & & & & & \\
\hline Operating profit & 2.518 & 3.344 & 0.000 & & & & & \\
\hline \multicolumn{9}{|c|}{ Dependent Variable: Islamic EPS } \\
\hline \multicolumn{4}{|c|}{$\begin{array}{c}\text { Traditional Model } \\
E P S_{i, t}=\alpha_{i, t}+\beta_{1} T D_{i, t}+\beta_{2} N D_{i, t}+\beta_{\%} O P_{i, t}+\varepsilon_{i, t}\end{array}$} & $\mathbf{R}$ & $\mathbf{R}^{2}$ & $\begin{array}{c}\text { Adjusted } \\
\mathbf{R}^{2} \\
\end{array}$ & $F$ & Sig. \\
\hline variables & Coefficient (B) & $\mathbf{t}$ & Sig. & 0.576 & 0.332 & 0.206 & 2.984 & 0.048 \\
\hline Constant & 0.398 & 3.627 & 0.012 & & & & & \\
\hline Term Deposits & 0.029 & 0.183 & 0.857 & & & & & \\
\hline $\begin{array}{l}\text { Deposits with } \\
\text { notification }\end{array}$ & 1.143 & 2.436 & 0.027 & & & & & \\
\hline Operating profit & 0.919 & 4.2 & 0.000 & & & & & \\
\hline
\end{tabular}

\subsection{Testing Hypotheses}

The multiple regression was relied in order to test the study's hypotheses, which are related to the effect of investment deposits on the EPS of conventional and Islamic banks. The results of the regression test are displayed in Table 4.

Table 4 shows that each of the independent variables combined (specified investment deposits, joint investment deposits and operating income) explain $81 \%$ change in the EPS for Jordanian Islamic banks, whereby the value of Adjusted $\mathrm{R}^{2}$ stood at 0.811 . Moreover, the $\mathrm{F}$ value for the Islamic banks model shows that $\operatorname{Sig}(\mathrm{F})$ was 0.00 , indicating the significance of the regression model, thus proving that there is a statistically significant effect of specified investment deposits, joint investment deposits and operating income on the EPS of Jordanian Islamic banks. Hence, the null hypothesis is rejected and the alternative hypothesis is accepted, which states, "There is a statistically significant effect of investment deposits (specified and joint) in the light of operating income as a controlling variable, on the earnings per share of Islamic banks".

Furthermore, the results of the multiple regression test displayed in Table 4 show that the regression coefficient for specified investment deposits was 0.032 , and was at a level of significance at 0.788 , meaning that there is no statistically significant effect of specified investment deposits on the EPS of Jordanian Islamic Banks at a significance level of $\alpha \leq 0.05$. This result is in line with Rashdan's (2009) study, which concluded that specified investments deposits have no effect on the profitability of Jordanian Islamic banks. However, the results of our study differ than those of Saadah, et al (2017) and Obeidat (2013), which concluded that specified investment deposits have a positive effect on the profitability of Jordanian Islamic banks.

The results of the multiple regression test in Table 4 also show that the regression coefficient for joint investment deposits amounted to 1.365 , at a significance level of 0.00 , meaning that joint investment deposits at Jordanian Islamic banks, at a level of significance of $\alpha \leq 0.05$, have a positive effect on the EPS. This result is in line with conclusions made by the following studies: Saadah et al., (2017), Al Adwan (2014) and Obeidat (2013), all of whom reached the conclusion that joint investment deposits have a positive effect on the profitability of Jordanian Islamic banks. However, this result differed from that of the Rashdan (2009), which showed a negative effect for joint investment deposits on the profitability of Jordanian Islamic Banks. It also differs from the Al Kassim (2005), which concluded that joint investment deposits have a negative effect on the profitability of Islamic banks in Gulf countries. 
Table 4 shows that each of the independent variables combined (term deposits, deposits with notification and operating income) explain $20.6 \%$ change in the EPS for Jordanian conventional banks, whereby the value of the Adjusted $\mathrm{R}^{2}$ stood at 0.206 . Moreover, the significance of value of $\mathrm{F}$ for the conventional banks model shows that Sig (F) was 0.048 , indicating the significance of the regression model, proving that there is a statistically significant effect of term deposits, deposits with notification and operating income on the EPS of Jordanian conventional banks. Therefore, the null hypothesis is rejected and the alternative hypothesis is accepted, which states, "There is a statistically significant effect of investment deposits (term deposits and deposits with notification) in the light of operating income as a controlling variable, on the Earnings per Share of Jordanian conventional banks".

The multiple regression analysis test results displayed in Table 4 show that the regression coefficient for term deposits amounted to 0.029 , at a significance level of 0.857 , meaning that term deposits at Jordanian conventional banks do not have a statistically significant effect on EPS, at a level of significance of $\alpha \leq 0.05$. This result differs from that of the Al Sarayre (2010) study, which concluded that term deposits have a positive effect on the profitability of Saudi conventional banks, in addition to Al Kassim (2005), which also concluded that term deposits have a positive effect on the profitability of Gulf country conventional banks.

The multiple regression analysis test results displayed in Table 4 also show that the regression coefficient for deposits with notification amounted to 1.143 , at a significance level of 0.027 , which means the deposits with notification at Jordanian conventional banks have a statistically significant effect on EPS, at a significance level of $\alpha \leq 0.05$. This result was in line with the Al Sarayre (2010) study, which concluded that deposits with notification have a positive effect on the profitability of Saudi conventional banks, in addition to Al Kassim (2005) study, which concluded that deposits with notification have a positive effect on the profitability of Gulf country conventional banks.

\section{Conclusion and Recommendations}

The study reached a number of results, the most important of which were as follows:

The high Adjusted $\mathrm{R}^{2}$ when it comes to explaining the change in EPS for Islamic banks model, compared to conventional banks, is a result of the high difference between investment deposits (specified and joint) at Jordanian Islamic banks and investment deposits (term deposits and deposits with notification) at Jordanian conventional banks. Hence, the Adjusted $\mathrm{R}^{2}$ amounted to $81.1 \%$ for Islamic Banks, while it amounted to $20.6 \%$ for conventional banks. This confirms how important it is for the banking sector to invest investment deposits in accordance to the tolerant teachings of Islamic Sharia, and to distribute the profits or losses that may be generated from these investments, rather than usurious interest.

The results of the study also show the positive effect that joint or general investment deposits have on the EPS, compared to specified investment deposits. This confirms how important it is for depositors to place their funds in joint investment deposits at Islamic banks, thus generating benefits and profits for both the depositors and shareholders of Islamic banks, especially through participation in investment projects managed efficiently. This in turn would provide momentum for the country's economy, and would lead to an increase in employment, thus reflecting on the country's ability to achieve sustainable development. This is especially true since the funds of joint investment deposit owners constitute a major source of deposits for Islamic banks. These types of depositors are considered as partners when it comes to profit sharing, and they also bear any losses incurred. Hence, they are considered as investors rather than lenders. All this requires them to be aware of how their funds are being used, which is done by publishing sufficient information regarding the uses of their funds and the profits made or losses suffered, within the banks' financial statements.

In addition, Islamic Banks need to disclose how profits are distributed between depositors and the bank shareholders, and the profit ratio of investment deposits relative to their investments. All of this information enables depositors to determine how efficient the bank's management has been at investing their funds. Therefore, it is important for Islamic banks to follow practical, methodological and transparent approaches to calculate the rates of Murabaha profit margins between shareholders and depositors, taking into consideration some of the issues which could be harmful for the competition between Islamic and conventional banks.

The results of the statistical analysis also show that deposits with notification at conventional banks have a positive effect on the profitability of conventional banks. This is shown in Table 3, whereby the percentage of deposits with notification at Jordanian conventional banks is higher than the percentage of term deposits. It can therefore be concluded that deposits which are not restricted by strict conditions, especially term deposits, have had a positive effect on the profitability of conventional banks.

The study recommends that the Central Bank needs to reevaluate the mandatory cash reserve ratio applied to investment deposits, so as to ensure that investor's funds are not obstructed with the Central Bank regulations, and in order to allow these funds to be injected into various investment opportunities. In general, it is noted that there is a large discrepancy between the returns generated for the lenders of investment deposits and the EPS for shareholders, especially 
if we take into consideration that both parties bear investment risks. Hence, it is important for banks, whether Islamic or conventional, to be fair when it comes to distributing profits to shareholders and depositors, and to balance between the interests of all stakeholders. Moreover, they should ensure that there isn't a large discrepancy in the profits distributed between shareholders and depositors. It is also important for conventional and Islamic banks to diversify their investments and financing instruments so as to reduce risks, in addition to attracting savings and diversifying the different types of accounts and deposits that they hold. The managements of Islamic banks should also adopt a uniform method to combine speculative funds, so as to reduce the differences and simplify comparisons between them, whilst working to develop and improve Islamic banking performance. Finally, the study recommends that further research should be conducted on the factors which influence how depositors decide on which type of deposit account to invest in, whether in conventional or Islamic banks. Moreover, almost all previous studies have been conducted at a local level, and it is important to expand the scope of future research to include international comparisons.

\section{References}

Abdullah, K. A., \& Saefan, H. (2011). Islamic Banking Operations (2nd ed.). Amman, Jordan: Jordan Wael for Publishing and Distribution.

Al Adwan, Y. (2014). Factors affecting the volume of deposits at Jordanian Islamic banks, for the period of 1999-2012. Unpublished PhD Thesis. The World Islamic Sciences and Education University, Amman, Jordan.

Al Ali, A. H. (2013). Managing Commercial Banks (1st ed.). Baghdad, Iraq: Thakera for Publishing and Distribution.

Al Fasfoos, F.S. (2010). Islamic Banks. Amman, Jordan: Kunouz Maarefa for Publishing and Distribution.

Al Kassim, F. (2005). The profitability of Islamic and conventional banking in the GCC countries: A comparative study. Master degree project. University of Wales Banger, United Kingdom.

Al Malkawi, A. (2012). The effect of the quality of banking services on the increase ability of Egyptian banks to compete. Unpublished PhD Thesis. Sadat Academy, Cairo, Egypt.

Al Rimawi, A. (2014). The risks and rights of joint investment account owners at Jordanian Islamic banks, Unpublished PhD Thesis. The World Islamic Sciences and Education University, Amman, Jordan.
Al Saifi, A., \& Al Salim, B.A. (2010). Investment deposits in Islamic banks: Allocating them and how their profits are distributed. Journal of Sharia Sciences and Law, 37(1), 202-220.

Al Sarayre, S. A. (2010). Determinants of profitability in Saudi commercial banks. The Arab Journal of Management, 30(1), 79-112.

Baber, H. (2019). E-SERVQUAL and its impact on the performance of Islamic banks in Malaysia from the customer's perspective. Journal of Asian Finance, Economics and Business, 6(1), 169175. https://doi.org/10.13106/jafeb.2019.vol6.no1.169

Babker, A. O. (2000). The System of Protecting Deposits at Islamic Banks (1st ed.). Jeddah, Saudi Arabia: The Islamic Center for Research and Training.

Nguyen, D. D., \& Nguyen, A. H. (2020). The impact of cash flow statement on lending decision of commercial banks: Evidence from Vietnam. Journal of Asian Finance, Economics and Business, 7(6), 85-93. https://doi.org/10.13106/jafeb.2020. vol7.no6.085

Obeidat, Z. (2013). Determinants of financial performance of Jordanian Islamic and conventional banks using Tobin's $q$ and the return on assets, in light of the global financial crisis, an applied study for the period 1999-2012. Unpublished PhD Thesis. The World Islamic Sciences and Education University, Amman, Jordan.

Rashdan, M. A. (2009). Factors affecting the profitability of Jordanian Islamic banks: The case of Jordan Islamic bank. Master's Thesis. Yarmouk University, Irbid, Jordan.

Richardson, E. (2011). Islamic finance for consumers in Ireland: A comparative study of the position of retail-level Islamic finance in Ireland. Journal of Muslim Minority Affairs, 31(4). https://doi.org/10.1080/13602004.2011.630861

Saadah, Y., Al Zaydanyeen, H., \& Al Shaer, B. (2017). The effect of employing investment deposits on shareholder profitability: An applied study on Jordanian Islamic banks. The Jordanian Journal of Islamic Studies, 13(2), 267-290.

Saeed, A. S. (2014). Managing Banks and the Features of Banking (1st ed.). Baghdad, Iraq: Al Thakera for Printing and Publishing.

Tabash, M. I. (2019). An empirical investigation on the relation between disclosure and financial performance of Islamic banks in the United Arab Emirates. Journal of Asian Finance, Economics and Business, 6(4), 27-35. https://doi.org/10.13106/ jafeb.2019.vol6.no4.27

Usman, N., Andriyani, L., \& Pambuko, Z. B. (2019). Productivity of Islamic Banks in Indonesia: Social funds versus financial funds. Journal of Asian Finance, Economics and Business, 6(3), 115-122. https://doi.org/10.13106/jafeb.2019.vol6.no3.115 